\title{
VERSENYZŐ FIATALOK VERSENGÉS, GYŐZELEM ÉS VESZTÉS FOGALMÁNAK VIZSGÁLATA AZ ASSZOCIATÍV CSOPORTANALÍZIS TECHNIKA SEGÍTSÉGÉVEL*
}

\author{
PINCZÉS-PRESSING ZSUZSANNA ${ }^{1,2}$ - SEBESTYÉN NÓRA ${ }^{2}-$ \\ BERKICS MIHÁLY ${ }^{2,3}$ - FÜLÖP MÁRTA ${ }^{3}$ \\ ${ }^{1}$ ELTE Pszichológiai Doktori Iskola \\ ${ }^{2}$ MTA TTK Kognitív Idegtudományi és Pszichológiai Intézet \\ ${ }^{3}$ ELTE Pszichológiai Intézet \\ E-mail: zsuzsanna.pressing@yahoo.com
}

Beérkezett: 2014. október 10. - Elfogadva: 2014. december 20.

\begin{abstract}
Bár korábbi vizsgálatok alapján feltételezhetjük, hogy a tehetséges személyek pozitívabban viszonyulnak, és konstruktívabb megküzdést alkalmaznak versengő helyzetekben, mint átlagos társaik (FüLÖP, 1992; PINCZÉS-PRESSING és FÜLÖP, 2013), tudomásunk szerint jelenleg nem áll rendelkezésünkre eredmény azzal kapcsolatban, hogy a hasonlóan jó képességú, ám eltéró eredményeket felmutató személyek között van-e különbség abban, ahogy a versengésröl, a gyözelemröl és a vesztésről gondolkodnak. Ezért egy nagyobb vizsgálatsorozat részeként online asszociációs vizsgálatot végeztünk az Asszociatív Csoportanalizis Technika segítségével (SZALAY és BRENT, 1967) egy 400 fös életkor és nem szerint is illesztett minta bevonásával (átlagéletkor: 17,96 év), amelyben 200 eredményes, illetve 200 nem eredményes versenyzö szerepelt. Az alkalmazott hívószavak a versengés, a gyözelem és a vesztés voltak. Eredményeink szerint az eredményes csoport komplexebb és pozitívabb módon viszonyul a vizsgált fogalmakhoz. Az ö asszociációikban nagyobb hangsúlyt kap a versengés motivációs aspektusa, illetve a pozitív érzelmek. Esetükben a versengésre és a gyözelemre adott asszociációk az eredményre és a folyamatra egyaránt fókuszálnak, szemben a nem eredményes versenyzők inkább eredményorientált gondolkodásmódjával. Az eredményes versenyzők a vesztést inkább képesek lehetöségként értelmezni, és számos megküzdési módot kapcsolnak hozzá, míg a nem eredményes csoportra a vesztéssel kapcsolatos kevésbé elaborált megközelités jellemzö.
\end{abstract}

Kulcsszavak: Asszociatív Csoportanalízis Technika, versengés, gyözelem, vesztés, tehetség

*A tanulmány megírása során Fülöp Márta az OTKA K 104332 támogatásában részesült. 


\section{BEVEZETŐ}

A versenyek a kezdetek óta a tehetségazonosítás és -fejlesztés sarokkövének tekinthetőek (RILEY, 2011), már az i. e. I. században Marcus Verrius Flaccus, korának leghíresebb tanára is alkalmazta a versenyt pedagógiai eszközként (RILEY és KARNES, 2009). Hazánkban is komoly hagyományokra tekint vissza a tehetséges diákok versenyeztetése, a matematika területén például már a XIX. században olyan tanterven kívüli megmérettetések voltak elérhetőek a diákok számára, mint a méltán híres KöMaL, az Eötvös Verseny, 1923-tól az Országos Középiskolai Tanulmányi Verseny, a negyvenes évektől pedig az Arany Dániel Matematika Verseny és a Schweitzer Miklós Emlékverseny (CONNELly STOCKTON, 2012).

A magyar közoktatás és tehetséggondozás azóta is kifejezetten versenyorientált. Egy magyar, japán, amerikai összehasonlító vizsgálatban például azt találták a kutatók, hogy a három ország közül Magyarországon áll a legtöbb verseny az iskolások rendelkezésére. Míg a magyar általános iskolások 60\%-a vesz részt valamilyen versenyben, addig az amerikaiak $19 \%$-a, a japánoknak pedig csupán 0,5\%a (FÜlÖP és BERKICS, 2003). A versenyek hazánkban mára a tanulmányok teljes skáláját felölelik. A 2013/2014-es tanévben például az OKTV-n összesen 27 tantárgyból mérethették meg magukat a diákok (OKTV 2013/2014 - Összesített adatok, 2014). A nemzetközi versenykínálatban (KARNES és RILEY, 2005) bekövetkezett változások miatt a versenyek fó célja is bővülni látszik: a tehetségek szelekciója mellett a cél egyre inkább a fejlesztés gazdagítása, illetve inkluzív versenylehetőségek megteremtésére (CONNELLY STOCKTON, 2012).

Azonban, ahogy arra UDVARI (2000) is rámutat, a versenyek töretlen alkalmazása ellenére kevés kutatást találunk a témában. A tehetség és versengés, illetve versenyzés területén jelenleg rendelkezésünkre álló szakirodalom inkább anekdotikus, illetve főként kisszámú esettanulmányokra épül (például CHEN-YAO, 2011), esetleg a versengés és versenyzés csupán mellékszálként jelenik meg a vizsgálatokban (például BLOOM, 1985). A kevés, kifejezetten a tehetség és versenyek/versengés témakörében született tudományos munka leginkább arra koncentrál, hogy a strukturált versenyek milyen területeken járulhatnak hozzá közvetlenül a tehetséges személyek fejlődéséhez (például BicKNELL és RiLEY, 2012; CAMPBELL és Walberg, 2011; DÁvid, FÜlÖP, Pataky és Rudas, 2014; Karnes és Riley, 1996). Emiatt nagyon kevés adat áll rendelkezésünkre a mélyebb fogalmi összefüggésekkel kapcsolatban, vagyis arról, hogy maguk a tehetséges fiatalok hogyan viszonyulnak a versenyekhez és versengéshez, illetve arról, hogy az, ahogyan a tehetséges fiatalok gondolkodnak a versengésről, hatással lehet-e a teljesítményükre, beválásukra. Míg például Rimm (1986) még úgy gondolta, hogy az alulteljesítő tehetségek eredményei a versengő közeg destruktív hatásainak köszönhetőek, mi azt feltételezzük, hogy a versengő kontextus mindig a társított szubjektív jelentések tükrében nyer jelentést, és hat konstruktívan vagy kártékonyan a személy teljesítményére. Mindezek miatt úgy véljük, hogy ezen szubjektív jelentések vizsgálata különösen releváns.

Többek között a fenti kérdések megválaszolása is volt a célja annak a vizsgálatsorozatnak, amelyet a Magyar Tehetségsegítő Szervezetek Szövetségének 
(MATEHETSZ) támogatásával végeztünk 2014 folyamán. A vizsgálatban a trianguláció módszeréhez folyamodtunk, mely során félig strukturált mélyinterjúkkal, Asszociatív Csoportanalízis Technikával (SzALAY és BRENT, 1967; SzaLAY és DEESE, 1978) és önkitöltős kérdőívekkel vizsgáltuk a versenyekhez kapcsolódó attitűdöket, szubjektív jelentéseket, illetve a versenyek későbbi beválásra kifejtett hatását. Jelen tanulmányban az asszociációs vizsgálat eredményeit ismertetjük, mellyel a versenyeken részt vevő fiatalok által a versengéshez, győzelemhez és vesztéshez társított szubjektív jelentésekbe nyerhetünk betekintést. Jelenleg nincs tudomásunk más, hasonló módszertannal és kifejezetten tehetséges fiatalokkal készült kutatásról.

\section{Versengés koncepció a magyar társadalomban}

Hazánkban az elmúlt 25 évben megváltozott versengés ideológia ellenére meglehetősen ambivalensen értékelik a versengést (FÜLÖP, 2008; FÜLÖP, 2013). Kutatások rávilágítottak, hogy különböző korcsoportok és foglalkozási területek között is általános a nézet, miszerint a magyar társadalomban zajló versengés ellentmondásos, agresszív és immorális (FÜLÖP, 2000, FÜLÖP és PRESSING, 2012; ROSS, FÜLÖP és PERGAR KUSCER, 2006; FÜLÖP, 2013). A sikerhez nem kiemelkedő képességekre és szorgalomra, hanem jó kapcsolatokra és destruktív eszközökre van szükség (SZABÓ, 2012), ami miatt a versenyben sikeres személyekre vegyes érzésekkel tekintenek a magyarok (FÜLÖP és PRESSING, 2012), a győzelemhez pedig gyakran negatív érzelmek, például szégyen kapcsolódik (FÜLÖP, 2009). Vesztés esetén inkább negatív és főleg deaktiváló érzelmek a jellemzőek, valamint csökkent énhatékonyság (FÜLÖP, 2009; FÜLÖP, 2013). Bár a megkérdezettek elismerik, hogy a versengés maga elkerülhetetlen, alapvetően inkább negatívan viszonyulnak hozzá és kritikával illetik (FÜLÖP, 2013). Nyílt kérdésekre építő, kulturális összehasonlító vizsgálatok eredményeiből ezenfelül az is nyilvánvaló, hogy a magyarok versengésfelfogása más kultúrákkal összehasonlításban is lényegesen negatívabb (FÜLÖP, 2000, 2002).

\section{A tehetséges személyek viszonya a versenyhez és a versengéshez}

Más eredmények alapján ugyanakkor azt feltételezhetjük, hogy a tehetséges személyek alapvetően pozitívabban viszonyulnak a versengéssel járó helyzetekhez, mint átlagos társaik. Egy korai, longitudinális vizsgálatban WHITE, KABAN és ATTANUCCI (1979) például azt találták, hogy a tehetséges és átlagos gyerekek között a személyiségüket tekintve a legfőbb különbség a tehetségesek versengéshez való pozitívabb viszonya volt. Hasonlóan egy hazai longitudinális vizsgálat során a megkérdezett 12 éves tehetséges gyerekek többsége a versengést szintén vonzó és örömteli tevékenységként írta le. Győzelmüket főként belső tényezőknek tulajdonították, vesztés esetén pedig a többség képesnek bizonyult további fejlődésre és új célok kitűzésére (FÜLÖP, 1992). A Kutató Diákok Mozgalom egykori résztvevői- 
vel a közelmúltban készült kutatás szerint a tehetséges fiatalok lényegesen több pozitív funkciót tulajdonítanak a versenyeknek az életükben, mint negatív következményt, illetve döntő többségben a győzelemmel és a vesztéssel való megküzdés konstruktívabb mintázatai jellemzőek rájuk. A győzelemre leginkább pozitív, aktiváló érzelmekkel reagáltak, míg a vesztést érzelmileg ugyan megterhelő, de nagyon fontos előrevivő tényezőként írják le (PINCZÉs-PrESSING és FüLÖP, 2013). Mindazonáltal eddig nem rendelkezünk információval arról, hogy a hasonlóan jó képességű, ám versenyeken eltérően sikeres fiatalok között van-e különbség a versengéshez való viszonyuk szempontjából.

\section{A versengés asszociációs vizsgálatával kapcsolatos eddigi eredmények}

A múlt évszázad közepére alakult ki az a két irányzat, mely napjainkig meghatározó az asszociációkkal történő kutatásban: 1 . a Moscovici-féle szociális reprezentáció elméletére építő iskola (ide tartozik például az ún Verges-módszer (VERGES, 1994)), illetve 2. az amerikai gyökerekkel rendelkező, Szalay és munkatársai (Szalay és BRent, 1967; Szalay és Deese, 1978) nevéhez köthető Asszociatív Csoportanalízis Technikára építő irányzat (FÜLÖP, 2013). Mára bár korlátozott számban, de mindkét fenti irányzat módszertanával rendelkezésünkre állnak a versengés témaköréhez szorosan kapcsolódó asszociációs vizsgálatok. ${ }^{1}$

A témában készült első kutatások között tartjuk számon FüLÖP, ROLAND-LEVY és BERKICS (2004), ROLAND-LEVY és FÜLÖP (2004), illetve OROSZ (2010) vizsgálatait, akik francia és magyar fiatalok versengéssel kapcsolatos szociális reprezentációját tárták fel a Verges-módszer segítségével. Ezek közül különösen érdekes számunkra Orosz (2010) tanulmánya, aki szerint míg a magyar egyetemistáknál egyértelműen azonosítható volt a versengéssel kapcsolatos eredményorientáció, addig a francia mintán a versengés folyamata és eredménye integrált módon jelent meg. SÁNDOR, OROSZ, és FÜLÖP (2010) 8-9 éves magyar gyerekek versengés-, győzelem- és vesztésreprezentációit vizsgálták a Verges- és az AGA módszer párhuzamos alkalmazásával. Ennek a tanulmánynak nagy érdeme, hogy a kutatók a két módszer összevetését is elvégezték, mely során az AGA-val kapott eredmények lényegesen árnyaltabbnak bizonyultak. A válaszok alapján a gyerekek a versengést leginkább mint sportversenyt értelmezik, a győzelem és a vesztés pedig érzelmileg erősen telített fogalmak a számukra. Az AGA módszerrel végzett kutatások közül a saját kutatásunk szempontjából talán a legnagyobb jelentőségű FÜLÖP (2013) vizsgálata, aki hat ország (Anglia, Magyarország, Törökország, India, Kína és Japán) fiatal felnőtteinek versengés fogalmát hasonlította össze. FÜLÖP (2013) eredményei szerint a magyar fiatalok elsősorban az eredményre fókuszálnak, illetve a versengés számukra ellenséges interperszonális kontextusba ágyazódik, hozzá számos negatív érzelem és konfliktus kapcsolódik. Ezzel szemben például a kínai fiatalok a versengés erőteljes motivációs aspektusát hangsúlyozták, és a hozzákapcsolt erőfeszítést emelték ki a válaszaikban, az általuk felvázolt kép nagyon dinamikus és folyamatorientált volt. 


\section{MÓDSZEREK}

\section{Résztvevók}

Az online adatfelvétel során különböző levelezőlistákon (például a Kutató Diákok Mozgalom, a MAFITUD, a Versenyzők Klubja, illetve a Tehetséghidak Program által működtetett tehetségfejlesztő szakkörök levelezőlistáin), illetve Tehetségpontokon és versenyfelkészítő tanárokon (például „Bonis Bona - A nemzet tehetségeiért” díjjal kitüntetett tanárokon) keresztül jutottunk el a résztvevőkhöz. A végső életkor és nem (valamint az idősebbek körében iskolai végzettség és lakóhely) szerint is illesztett mintába 200 eredményes versenyzőt (azaz olyan személyt, aki bevallása szerint részt vett versenyeken és legalább egy rangos, regionális/nemzeti/nemzetközi középiskolai versenyeredménnyel rendelkezik), illetve a kontrollcsoportba 200 nem eredményes versenyzöt (azaz olyan személyt, aki bár részt vett versenyeken, de nem rendelkezik kiemelkedő versenyeredményekkel) válogattunk be. A résztvevőket ajánló tanárokat arra kértük, hogy az eredményes diákjaikhoz hasonló képességủ diákjaikat ajánlják a kontrollcsoportba. Ezzel azt szerettük volna elérni, hogy a két csoport intellektuális teljesítményét tekintve hasonló háttérrel rendelkezzen. Mivel az asszociációs vizsgálatra egy nagy kutatás részeként került sor, ezért fontos megemlíteni, hogy a teljes kutatás keretében több mint egy tucat különböző kérdőívre válaszoltak a résztvevők. Mivel a teljes kérdőívcsomag elég hosszú volt, az első rész kitöltése után a válaszadó szabadon dönthetett, hogy folytatja-e a kitöltést. A végső mintába történő beválogatásnál ezért a demográfiai illeszkedés mellett az is szempont volt, hogy azokat részesítsük előnyben, akik a teljes kérdőívet kitöltötték, de legalább a kérdőív feléig eljutottak. Mivel Szalay és kollégái szerint már mintegy 50-100 résztvevővel lefedhetjük az adott populációban fellelhető válaszok eléggé széles és stabil skáláját (SZALAY, STROHL, Fu és LAO, 1994), ezért a csoportonként bevont 200-200 fő elegendő ahhoz, hogy akár önmagukban is értelmezhető almintákat képezzünk.

Eredeti terveink szerint egy harmadik csoportot is szerettünk volna megszólítani, azokat, akik bár jó képességekkel rendelkeznek, de nem versenyeztek középiskolában. Azonban az összes kitöltő között csupán 16 olyan személy volt, aki ebben az időszakban egyáltalán nem vett részt tanulmányi vagy sportversenyeken. Ez önmagában is figyelemre méltó, hiszen azt erősíti meg, hogy a jó képességű diákokat az esetek döntő többségében elküldik versenyezni Magyarországon.

A teljes illesztett minta átlagéletkora 17,96 év $(\mathrm{SD}=3,09)$. Mindkét csoportban némiképp több nő $(62,5 \%)$, mint férfi $(37,5 \%)$ szerepel. Az egyenlötlen nemi megoszlás ugyanakkor összhangban van FÜLÖP és BERKICS (2003) eredményeivel, akik szerint mind az USA-ban, mind Magyarországon arányaiban több lány vesz részt versenyeken. A résztvevők 12,3\%-a a fövárosban, 28,3\%-a megyeszékhelyen, 36,8\%-a vidéki városban, 21,3\%-a községben lakik.

\footnotetext{
${ }^{1}$ Az ide vonatkozó eredmények igen részletes ismertetéséért lásd még FÜLÖP, 2013.
} 


\section{Az Asszociatív Csoportanalizis Technika (AGA)}

Az említett asszociációs kutatások tanulságaira építve jelen kutatásban az AGA módszerre esett a választás. Az AGA módszer (SZALAY és BRENT, 1967; SzALAY és DEESE, 1978) korábbi tapasztalataink alapján remekül alkalmazható a fogalmakhoz társított szubjektív jelentések mély és komplex megismerésére (FüLÖP, 2013; PINCZÉS-PRESSING és FÜLÖP, 2013). Bár a módszert eleinte leginkább kulturális összehasonlító vizsgálatokban alkalmazták, az évtizedek során jól alkalmazhatónak bizonyult adott kultúrán belüli társadalmi csoportok összehasonlítására, illetve fogalmak fejlődésének a vizsgálatára is (FüLÖP, 2013). Az AGA lehetővé teszi, hogy a tudatos elvárások által kevésbé befolyásolt képet nyerjünk a fogalmakhoz kapcsolt jelentésekről. Mivel nem csupán a szavak szintjén zajlik az elemzés, hanem a kategorizálás révén komplex, hierarchikus struktúrákat is alkothatunk, alkalmasabb összetett interperszonális fogalmak értelmezésére (szemben például az említett Vergés-módszerrel). A módszernek hála viszonylag gyorsan juthatunk nagy mennyiségű információhoz, a kvalitatív adatok ráadásul remekül kvantifikálhatók is.

A papír-ceruza eljárás lényege, hogy a résztvevőknek egy perc áll rendelkezésükre, hogy bármilyen asszociációt, ami a hívószóval kapcsolatban eszükbe jut, leírjanak. A kapott asszociációkat az elemzés során súlyozzák és kategorizálják, aminek hála a kutatók részletes képet nyerhetnek egy adott fogalommal kapcsolatos szubjektív jelentések rendszerére vonatkozóan. A súlyozás azt képezi le, hogy az egyes jelentéstartalmak mennyire központiak a teljes jelentés szempontjából. A súlyozás során az elsőként említett asszociáció 6 pontot, majd a sorban következő asszociációk 5, 4, 3, 3, 3, 3, 2, 2 pontot, illetve minden ezután következő asszociáció pedig 1 pontot kap.

\section{A vizsgálat menete}

A vizsgálat során a résztvevők az e-mail címükre kapták meg a kérdőív kitöltéséhez szükséges linket. A szükséges nyilatkozatok kitöltését követően pár alapvető demográfiai információt adtak meg magukról, majd közvetlenül az asszociációs feladat következett, mivel szerettük volna elkerülni, hogy a többi kérdőív előfeszítő hatása torzítsa az eredményeket. Az asszociációkat az AGA módszer szerint rögzítettük, illetve tartalomelemeztük. A jelen vizsgálatban alkalmazott hívószavak a versengés, a gyózelem és a vesztés voltak, amelyeket random sorrendben mutattunk be az online felületen. A kategorizálást két kutató végezte, az esetleges eltérésekről konszenzus döntött. Az eredményes és nem eredményes csoport asszociációiból létrehozott kategóriák összsúlyait ezután Fischer-egzakt próbával vetettük egybe. A statisztikai elemzés során azt hasonlítottuk össze, hogy az összes súlyozott asszociáción belül egy-egy asszociációkategória milyen arányban szerepel a két csoport hívószavakkal kapcsolatos képzettársításában. Az abszolút összehasonlíthatóság kedvéért az összsúlyokat is közöljük, ám a szignifikanciapróbák ezekre nem önmagukban vonatkoznak, hanem az adott csoport összsúlyán belüli relatív helyük szerint. 


\section{EREDMÉNYEK}

Az eredményes versenyzők (a továbbiakban EV) mindhárom esetben valamivel több asszociációt írtak, így náluk az asszociációk súlyozott összege is nagyobb volt, mint a nem eredményes versenyzőknél (a továbbiakban NEV). ${ }^{2}$ Ez alapján az EV csoport vizsgált fogalmakkal kapcsolatos képzettársítása valószínűleg gyorsabb és a válaszok variabilitása alapján egyben gazdagabb is.

1. táblázat. Az asszociációk összsúlya a 3 hívószó esetén

\begin{tabular}{|l|c|c|c|c|}
\hline \multirow{2}{*}{ Hívószavak } & \multicolumn{2}{|c|}{$\begin{array}{c}\text { Eredményes versenyzők } \\
(\mathrm{N}=200)\end{array}$} & \multicolumn{2}{c|}{$\begin{array}{c}\text { Nem eredményes versenyzők } \\
(\mathrm{N}=200)\end{array}$} \\
\cline { 2 - 5 } & $\begin{array}{c}\text { Válaszok } \\
\text { száma/fö }\end{array}$ & Összsúly & $\begin{array}{c}\text { Válaszok } \\
\text { száma/fö }\end{array}$ & Összsúly \\
\hline Versengés & 5,55 & 4191 & 4,65 & 3653 \\
\hline Győzelem & 5,88 & 4355 & 4,92 & 3825 \\
\hline Vesztés & 4,44 & 3665 & 4,01 & 3397 \\
\hline
\end{tabular}

\section{Versengés}

A versengés szóra adott asszociációk összesen 13 fő kategóriába voltak sorolhatók (2. táblázat). Ezek a teljes minta összsúlyához viszonyított súlyozott előfordulásuk százalékos aránya szerint a következők: Motiváció, ambíció (25\%), Győzelem, vesztés (20\%), Negatív érzelmek, állapotok (13\%), Területek (12\%), Pozitív érzelmek, állapotok (8\%), Szinonimák (8\%), Emberek, résztvevők (3\%), Proszociális (3\%), Készségek, képességek (2\%), Egyéb (2\%), Élet/Az élet része (1\%), Moralitás (1\%), Evolúció (1\%).

Ahogy látható, mindkét csoportban legnagyobb súllyal a motivációhoz, illetve a versengés kimeneteléhez kapcsolható tartalmakat említettek a résztvevők, de a versengés területei, a versengés konkrét szinonimái, illetve a negatív és pozitív érzelmi állapotok is előkelő helyen szerepelnek.

Az EV csoport a versengésre szignifikánsan nagyobb összsúllyal említette a következő kategóriákba sorolható asszociációkat:

- Motiváció, ambíció (1194 > 798, p < 0,0001) - ide azok az asszociációk tartoznak, amelyek az erőfeszítésekre, a fejlődésre, a célokra, a motivációra és a teljesítményre vonatkoznak;

- Pozitíu érzelmek és állapotok (383 > 279, $p=0,0182)$ - például izgalom, öröm, szórakozás;

\footnotetext{
${ }^{2}$ Ezért az adott kategóriák súlyai mellett az összsúlyhoz viszonyított százalékos arányokat is közöljük a könnyebb értelmezhetőség érdekében.
} 
- A versengés az élet része $(90>10, p<0,0001)$ - például élet, életpálya, a dolgok rendje;

- Moralitás (83 > 20, $p<0,0001)$ - például fair play, szabályok, igazságosság;

- Evolúció (48 > 16, $p=0,0006)$ - például dominancia, túlélés.

2. táblázat. A versengés hívószóra adott asszociációk kategóriái az eredményes és a nem eredményes versenyző csoportnál

\begin{tabular}{|c|c|c|c|c|}
\hline Versengés & $\begin{array}{c}\text { Eredményes } \\
\text { súly }\end{array}$ & $\%$ & $\begin{array}{l}\text { Nem eredmé- } \\
\text { nyes súly }\end{array}$ & $\%$ \\
\hline Motiváció, ambíció & $1194^{*}$ & $28,5 \%$ & 798 & $22 \%$ \\
\hline Erőfeszítés & 468 & $11 \%$ & 338 & $9 \%$ \\
\hline Motiváció & 336 & $8 \%$ & 219 & $6 \%$ \\
\hline Fejlődés & 209 & $5 \%$ & 139 & $4 \%$ \\
\hline Teljesítmény & 111 & $3 \%$ & 60 & $2 \%$ \\
\hline Cél & 70 & $2 \%$ & 42 & $1 \%$ \\
\hline Győzelem, vesztés & 717 & $17 \%$ & $815^{*}$ & $22 \%$ \\
\hline Győzelem & 568 & $14 \%$ & 595 & $16 \%$ \\
\hline Vesztés & 146 & $3 \%$ & 207 & $6 \%$ \\
\hline Győzelem-vesztés & 3 & $0 \%$ & 13 & $0 \%$ \\
\hline Területek & 511 & $12 \%$ & 431 & $12 \%$ \\
\hline Sport & 201 & $5 \%$ & 208 & $6 \%$ \\
\hline Oktatás/tanulmányi versenyek & 192 & $5 \%$ & 102 & $3 \%$ \\
\hline Gazdaság, munka & 75 & $2 \%$ & 64 & $2 \%$ \\
\hline Társadalom & 32 & $1 \%$ & 21 & $1 \%$ \\
\hline Egyéb & 11 & $0 \%$ & 36 & $1 \%$ \\
\hline Negatív érzelmek, állapotok & 496 & $12 \%$ & $502^{*}$ & $14 \%$ \\
\hline Negatív érzelmi állapotok & 237 & $6 \%$ & 207 & $6 \%$ \\
\hline Harc, háború & 141 & $3 \%$ & 206 & $6 \%$ \\
\hline Demotiváció, gátlás & 43 & $1 \%$ & 6 & $0 \%$ \\
\hline Konfliktus & 39 & $1 \%$ & 55 & $2 \%$ \\
\hline Agresszió & 36 & $1 \%$ & 28 & $1 \%$ \\
\hline Pozitív érzelmek, állapotok & $383^{*}$ & $9,14 \%$ & 279 & $7,64 \%$ \\
\hline Emberek, résztvevők & 131 & $3,13 \%$ & 118 & $3,23 \%$ \\
\hline Proszociális & 108 & $2,58 \%$ & $165^{*}$ & $4,52 \%$ \\
\hline Élet/az élet része & $90^{*}$ & $2,15 \%$ & 10 & $0,27 \%$ \\
\hline Készségek, képességek & 80 & $1,91 \%$ & 86 & $2,35 \%$ \\
\hline Moralitás & $83^{*}$ & $1,98 \%$ & 20 & $0,55 \%$ \\
\hline Evolúció & $48^{*}$ & $1,15 \%$ & 16 & $0,44 \%$ \\
\hline Szinonima & 284 & $6,78 \%$ & $343^{*}$ & $\mathbf{9 , 3 9 \%}$ \\
\hline Egyéb & 66 & $1,57 \%$ & 70 & $1,92 \%$ \\
\hline Összesen & 4191 & $100 \%$ & 3653 & $100 \%$ \\
\hline
\end{tabular}

A táblázatban ${ }^{*}$ jelöli azt a csoportot, amely szignifikánsan nagyobb súllyal említette az adott kategóriát, $p>0,05$. 
A NEV csoport ugyanakkor az eredményeseknél nagyobb súllyal asszociált az alábbi kategóriákba sorolt tartalmakra:

- Gyözelem és vesztés $(717<815, p<0,0001)$. A nem eredményes versenyzők nem csupán a vereségre asszociáltak relatíve nagyobb súllyal $(146<207$, $p<0,0001)$, hanem a győzelemre is $(568<595, p=0,0007)$. Fontos továbbá megemlítenünk, hogy a győzelemre mindkét csoport alapvetően nagyobb súllyal asszociált;

- Negatív érzelmek és állapotok $(496<502, p=0,012)$ - például stressz, fáradtság, nyomasztó;

- Szinonimák $(284<343, p<0,0001)$ - például verseny, kompetíció.

- Proszociális tartalmak $(108<165$, $\mathrm{p}<0,0001)$ - például barátság, csapatszellem, segítség.

Ahogy látható, az EV csoport leginkább komplex motivációs „eszközként” tekint a versengésre. Ezzel szemben a NEV csoport képzettársításában a versengés motivációs aspektusa, illetve eredménye azonos mértékben fontos. A győzelem és vesztés, illetve főként a győzelem, náluk szerepel nagyobb hangsúllyal, ami egyfajta eredményorientációra, a végkifejlet nagyobb szubjektív fontosságára utalhat. A korábbi, magyar egyetemista mintán végzett kutatásokkal (FÜLÖP, 2013) szemben a pozitív és negatív érzelmek aránya kiegyenlítettebb az általunk vizsgált csoportokon, és ez különösen igaz az EV csoportra. Úgy tűnik, hogy ők alapvetően pozitívabban gondolkodnak a versengésről, ám még a NEV csoport is kevesebb negatív érzelmet és több pozitív érzelmet sorol fel, mint az átlagos magyar egyetemisták. (Az 5\% alatti arányban szereplő kategóriák esetén azonosított szignifikáns csoportközi eltérések jelentősége valószínűleg korlátozott, ezért ezekre most nem térünk ki.)

A legnagyobb súlyú asszociációkat tekintve szembetűnő, hogy míg a NEV csoport esetén a tíz legnagyobb súlyú asszociációból a versengés eredményével kapcsolatban mind a győzelemre, mind a vesztésre vonatkozó asszociációk szerepelnek, addig az EV-knél csak a győzelem, siker és nyerés jelenik meg. Ez egy sokkal optimistább képet sugall a versenyekkel kapcsolatban, ami persze korántsem meglepő a kialakított csoportok alapjellemzői miatt. A NEV csoportnál emellett rögtön a harmadik leggyakoribb asszociáció a harc, ami a versengéssel kapcsolatos negatívabb attitűd kifejeződése lehet. Az EV csoportban emellett három a motivációhoz és a folyamatorientáltabb gondolkodásmódhoz szorosan kapcsolható elem is feltűnik a legnagyobb súlyú asszociációk között, nevezetesen a kihívás, a küzdelem és a kitartás, míg a nem eredményes versenyzőknél csak egy. 
3. táblázat. A legnagyobb súllyal szereplő asszociációk (Versengés)

\begin{tabular}{|c|c|c|c|c|}
\hline & \multicolumn{2}{|l|}{ Eredményes versenyzők } & \multicolumn{2}{|l|}{ Nem eredményes versenyzők } \\
\hline 1 & Győzelem, győzni, győztes & 245 & Győzelem, győzni, győztes & 282 \\
\hline 2 & Verseny, versenyzés, versenyző & 169 & $\begin{array}{l}\text { Verseny, versenyek, versenyen, ver- } \\
\text { senyző }\end{array}$ & 212 \\
\hline 3 & Kihívás, kihívások & 100 & Harc & 128 \\
\hline 4 & Siker & 93 & Küzdelem, küzdés & 125 \\
\hline 5 & Küzdelem, küzdés & 90 & Izgalom & 90 \\
\hline 6 & Harc, harcos & 89 & $\begin{array}{l}\text { Nyeremény, nyerés, nyerni, nyertes, } \\
\text { nyereség }\end{array}$ & 86 \\
\hline 7 & Izgalom, izgalmas & 73 & Vereség & 70 \\
\hline 8 & $\begin{array}{l}\text { Nyeremény, nyerni, nyerés, nyertes, } \\
\text { nyereség }\end{array}$ & 71 & Veszíteni, vesztes, vesztés & 65 \\
\hline 9 & Kitartás & 70 & Sport & 50 \\
\hline 10 & Tanulás, tanulmány, tanulmányok & 62 & Ellenfél, ellenfelek & 49 \\
\hline
\end{tabular}

\section{Gyözelem}

A győzelem hívószó esetén kialakított kategóriákkal kapcsolatban elmondható, hogy összességében jól megragadják a győzelem feldolgozásának a folyamatát, beleértve a győzelemhez kapcsolódó intenzív érzelmi élményt, a feldolgozás során végbemenő attribúciós folyamatot, a többnyire valamilyen viselkedésben is megjelenő reakciót, valamint a társas környezetünk helyzethez kapcsolódó visszajelzéseit és azok elaborációját. ${ }^{3}$

Az elemzés során kialakított 13 fő kategória így a következő volt a teljes mintára vonatkozóan: Érzelmek (37\%, döntően pozitív érzelmek), Eredményorientáció (17\%), Attribúció (13\%), Győzelem területei (8\%), Társas reakció (6\%), Győzelem utáni reakció (5\%), Szinonima (5\%), Verseny (4\%), Harc (2\%), Társak, társas támogatás $(1 \%)$, Vereség (1\%), Egyéb (1\%), Moralitás $(<1 \%)$.

Látható, hogy a vizsgált minta győzelem reprezentációja erősen fókuszált, a képzettársítás nagy részét a győzelemmel kapcsolatban fellépő, döntően pozitív érzelmek uralják. Nagy arányban szerepelnek az eredményorientációt megragadó válaszok is, melyek kifejezetten a verseny hozadékára vonatkoznak, legyen az bár valamiféle kézzelfogható vagy szimbolikus nyeremény, vagy akár személyes fejlődés. A harmadik legnagyobb kategória a győzelemhez kapcsolódó lehetséges attribúciókat tartalmazza. Erdekes módon mindkét csoportra jellemző, hogy a fókusz inkább a győzelemhez kapcsolódó érzelmekre, jutalmakra/eredményekre, illetve a mögöttes okokra helyeződik. A győzelmet kísérő reakciók jóval kisebb arányban szerepelnek, a győzelemmel való viselkedéses megküzdés (illetve annak szükségessége) csak perifériás része a reprezentációnak.

\footnotetext{
${ }^{3}$ Az eredményül kapott kategóriarendszer remekül illeszkedett a kérdőíves vizsgálatban alkalmazott Győzelemmel és Vesztéssel Való Megküzdés kérdőív (FüLÖP, 2013) struktúrájához is.
} 
4. táblázat. A győzelem hívószóra adott asszociációk kategóriái az eredményes és a nem eredményes versenyző csoportnál

\begin{tabular}{|c|c|c|c|c|}
\hline \multirow{2}{*}{ G yő z e 1 e m } & \multicolumn{2}{|c|}{ Eredményes } & \multicolumn{2}{|c|}{ Nem eredményes } \\
\hline & Súly & $\%$ & Súly & $\%$ \\
\hline Érzelmek & 1542 & $35 \%$ & $1474^{*}$ & $39 \%$ \\
\hline pozitív érzelmek & 1523 & $35 \%$ & 1413 & $37 \%$ \\
\hline negatív érzelmek & 15 & $0 \%$ & 44 & $1 \%$ \\
\hline vesztessel kapcsolatos proszociális érzelmek & 4 & $0 \%$ & 17 & $0 \%$ \\
\hline Eredményorientáció & 731 & $17 \%$ & 650 & $17 \%$ \\
\hline Nyeremény & 341 & $8 \%$ & $414^{*}$ & $11 \%$ \\
\hline Célelérés, teljesítmény, helyezés & 227 & $5 \%$ & 177 & $5 \%$ \\
\hline Fejlődés, tapasztalat & $163^{*}$ & $4 \%$ & 59 & $2 \%$ \\
\hline Attribúció & 691 & $16 \%$ & 338 & $9 \%$ \\
\hline Belső & $648^{*}$ & $15 \%$ & 308 & $8 \%$ \\
\hline Erőfeszítés & 374 & $9 \%$ & 179 & $5 \%$ \\
\hline Képesség & 134 & $3 \%$ & 68 & $2 \%$ \\
\hline Motiváció & 90 & $2 \%$ & 26 & $1 \%$ \\
\hline Hozzáállás & 30 & $1 \%$ & 35 & $1 \%$ \\
\hline Stratégia & 20 & $0 \%$ & 0 & $0 \%$ \\
\hline Külső & 43 & $1 \%$ & 30 & $1 \%$ \\
\hline Terület & $365^{*}$ & $8 \%$ & 252 & $7 \%$ \\
\hline Oktatás & 102 & $2 \%$ & 51 & $1 \%$ \\
\hline Sport & 100 & $2 \%$ & 105 & $3 \%$ \\
\hline Munka & 92 & $2 \%$ & 46 & $1 \%$ \\
\hline Élet & 31 & $1 \%$ & 0 & $0 \%$ \\
\hline Szórakozás & 25 & $1 \%$ & 28 & $1 \%$ \\
\hline Társadalom, politika & 11 & $0 \%$ & 11 & $0 \%$ \\
\hline Művészet & 4 & $0 \%$ & 11 & $0 \%$ \\
\hline Győzelem utáni reakció & 206 & $5 \%$ & 171 & $4 \%$ \\
\hline Énhatékonyság növelése & 119 & $3 \%$ & 100 & $3 \%$ \\
\hline Énfelnagyítás & 32 & $1 \%$ & 30 & $1 \%$ \\
\hline Önszabályozás & 16 & $0 \%$ & 0 & $0 \%$ \\
\hline Aktiváció & 15 & $0 \%$ & 30 & $1 \%$ \\
\hline Zavar & 15 & $0 \%$ & 0 & $0 \%$ \\
\hline Kiengedés & 9 & $0 \%$ & 11 & $0 \%$ \\
\hline Társas reakció & 250 & $6 \%$ & 245 & $6 \%$ \\
\hline Pozitív & 244 & $6 \%$ & 241 & $6 \%$ \\
\hline Negatív & 6 & $0 \%$ & 4 & $0 \%$ \\
\hline Verseny & 179 & $4 \%$ & 182 & $5 \%$ \\
\hline Társak, társas támogatás (személyek, csapat) & 63 & $1 \%$ & 48 & $1 \%$ \\
\hline Harc & 47 & $1 \%$ & $105^{*}$ & $3 \%$ \\
\hline Vereség & 42 & $1 \%$ & 37 & $1 \%$ \\
\hline Moralitás & 17 & $0 \%$ & 11 & $0 \%$ \\
\hline Szinonima & 162 & $4 \%$ & $275^{*}$ & $7 \%$ \\
\hline Egyéb & 60 & $1 \%$ & 37 & $1 \%$ \\
\hline Összes súly & 4355 & $100 \%$ & 3825 & $100 \%$ \\
\hline
\end{tabular}

A táblázatban " jelöli azt a csoportot, amely szignifikánsan nagyobb súllyal említette az adott kategóriát. 
Az EV-k a győzelemmel kapcsolatban szignifikánsan nagyobb súllyal említették az alábbi kategóriákba és alkategóriába sorolt asszociációkat:

- Eredményorientáció/Fejlődés, tapasztalat $(163>59, p<0,001)$ - például fejlödés, előrejutás;

- Belső attribúció (648 > 308, $p<0,0001)$ - például kitartás, motiváció, tudás;

- A versengés területei $(365>252, p=0,0022)$ - például iskola, sport, munka; ezen belül az eredményesek nagyobb súllyal asszociáltak az oktatásra (102 $>51, p=0,0008)$.

A következő típusú asszociációkat ugyanakkor a NEV-k említették nagyobb súlylyal:

- Érzelmek $\left(1542<1474^{4}, p=0,0035\right)$ - túlnyomó többségben pozitív érzelmek, például öröm, boldogság, büszkeség;

- Eredményorientáció/Nyeremény $(341<414, p<0,001)$, például helyezés, eredmény;

- Szinonima $(162<275, p<0,0001)$ - például nyerés, victory;

- Harc $(47<105, \mathrm{p}<0,0001)$ - például harc, háború, csata.

Külön említést érdemel az Eredményorientáció kategória alkategóriáinál talált szignifikáns eltérés, mely véleményünk szerint egy igen fontos különbségre világít rá. Habár a győzelemhez kapcsolódó nyeremények mindkét csoport számára fontosak, jelentőségük nagyobb a NEV csoport esetén, míg a győzelemhez vezető út során elért fejlődés és tapasztalat inkább az EV-knél jelenik meg. Így bár elmondhatjuk, hogy a magyarokra általában jellemző eredményorientáció (lásd például SEBESTYÉN és FÜLÖP [2015] tanulmányát jelen kötetben, a 143-158. oldalon) mindkét csoportban megjelenik, az EV csoportban egy, a folyamatra érzékenyebb kép rajzolódik ki.

A legnagyobb súlyú asszociációkat vizsgálva láthatjuk, hogy az első tíz asszociációban számos közös elem van, melyek 1-2 hely eltéréssel mindkét csoportban fellelhetőek. Ugyanakkor az EV-k esetén a munka mint asszociáció megjelenése az elért eredmény mögött feltételezett belső, kontrollálható attribúciót jeleníti meg, és a komplexebb elaboráció irányába mutat. A NEV-knél az első tízben leginkább csak pozitív érzelmek, illetve a versengéshez kapcsolódó különböző jutalmak jelennek meg, valamint ismételten a harc, mely a versengéssel és győzelemmel kapcsolatos ambivalenciát mutathatja.

\footnotetext{
${ }^{4}$ A relációjel magyarázata: az 1474-es súly a nem eredményesek között relatíve nagyobbnak számít, mivel náluk az összes súly összege 3825, míg az eredményeseknél 4355.
} 
5. táblázat. A legnagyobb súllyal szereplő asszociációk (Győzelem)

\begin{tabular}{|c|c|c|c|c|}
\hline & \multicolumn{2}{|l|}{ Eredményes versenyzők } & \multicolumn{2}{|l|}{ Nem eredményes versenyzők } \\
\hline 1 & Siker, sikerül & 422 & Öröm & 344 \\
\hline 2 & Öröm, örül & 326 & Siker, sikerült & 340 \\
\hline 3 & Boldog, boldogság & 165 & $\begin{array}{l}\text { Nyer, nyeremény, nyeremények, } \\
\text { nyerni, nyerés, nyertes }\end{array}$ & 200 \\
\hline 4 & Verseny, versenyek, versenyzés & 146 & Boldogság & 200 \\
\hline 5 & Elismerés, elismertség & 120 & $\begin{array}{l}\text { Verseny, versenyek, versenyzés, } \\
\text { versenyző }\end{array}$ & 128 \\
\hline 6 & Büszke, büszkeség & 95 & Büszkeség & 98 \\
\hline 7 & $\begin{array}{l}\text { Nyeremény, nyertes, nyerés, nyer- } \\
\text { tem, nyerni, nyereség }\end{array}$ & 85 & Elismerés, elismertség & 77 \\
\hline 8 & Munka & 83 & Díj, díjak & 72 \\
\hline 9 & Jutalom & 78 & Dicsőség & 68 \\
\hline \multirow{2}{*}{10} & Dicsőség & 75 & \multirow{2}{*}{ Harc } & \multirow{2}{*}{64} \\
\hline & Elégedettség & 75 & & \\
\hline
\end{tabular}

Vesztés

A vesztés hívószóra adott asszociációkat összesen 12 fő kategóriába soroltuk: Érzelmek (37\%, döntően negatív érzelmek), Megküzdés (17\%), Szinonima (16\%), Vesztés mint fejlődési lehetőség (7\%), A vesztés területei (5\%), Attribúció (4\%), Verseny (3\%), Győzelem (3\%), Egyéb (3\%), Agresszió, háború (2\%), Negatív társas reakciók (2\%), Társak, társas támogatás $(1 \%)$.

A jelentés itt is erősen fókuszált, a győzelemhez hasonlóan mindkét csoportnál az érzelmek, méghozzá elsősorban a negatív érzelmek állnak a középpontban. Azokat az EV csoportban a vesztés élményével való megküzdés (fóként az aktív megküzdés és leginkább az ismételt erőfeszítés és vesztés utáni talpra állás), a NEV-knél pedig a vesztés szinonimáit összesítő kevésbé összetett kategória követi (6. táblázat).

Az EV-k szignifikánsan nagyobb relatív súllyal asszociáltak a következőkre:

- Aktív megküzdés $(655>313, p<0,0001)$ - például újrakezdés, kitartás;

- Passzív megküzdés $(167>58, p<0,0001)$ - például elfogadás, beletörődés;

- A vesztés mint lehetőség $(356>118, p<0,0001)$ - például tapasztalat, tanulság, fejlődés;

- Attribúciók/külső attribúciók (48 > 11, p < 0,0001) - például mások, pech, csalás;

- Társas támogatás $(45>13, p<0,0001)$ - például barát, családtag, beszélgetés. 
6. táblázat. A vesztés hívószóra adott asszociációk kategóriái az eredményes és a nem eredményes versenyző csoportnál

\begin{tabular}{|c|c|c|c|c|}
\hline \multirow{2}{*}{ Vesztés } & \multicolumn{2}{|c|}{ Eredményes } & \multicolumn{2}{|c|}{ Nem eredményes } \\
\hline & Súly & $\%$ & Súly & $\%$ \\
\hline Érzelmek & 1136 & $31 \%$ & $1474^{*}$ & $43 \%$ \\
\hline Negatív érzelmek, állapotok & 1087 & $30 \%$ & 1435 & $42 \%$ \\
\hline Deaktiváló & 648 & $18 \%$ & 936 & $28 \%$ \\
\hline Aktiváló & 339 & $9 \%$ & 366 & $11 \%$ \\
\hline Differenciálatlan & 100 & $3 \%$ & 133 & $4 \%$ \\
\hline Pozitív érzelmek állapotok & 49 & $1 \%$ & 39 & $1 \%$ \\
\hline Megküzdés & 822 & $22 \%$ & 371 & $11 \%$ \\
\hline Aktív megküzdés & $655^{*}$ & $18 \%$ & 313 & $9 \%$ \\
\hline Ismételt erőfeszítés, talpra állás & 555 & $15 \%$ & 217 & $6 \%$ \\
\hline Helyzetelemzés & 58 & $2 \%$ & 53 & $2 \%$ \\
\hline Feladás, aktív elkerülés & 31 & $1 \%$ & 37 & $1 \%$ \\
\hline Módosított cél & 11 & $0 \%$ & 6 & $0 \%$ \\
\hline Passzív megküzdés & $167^{*}$ & $5 \%$ & 58 & $2 \%$ \\
\hline Elfogadás, az élet része & 138 & $4 \%$ & 58 & $2 \%$ \\
\hline Pihenés & 17 & $0,5 \%$ & 0 & $0 \%$ \\
\hline Hit & 9 & $0 \%$ & 0 & $0 \%$ \\
\hline Érzelmi kitörés & 3 & $0 \%$ & 0 & $0 \%$ \\
\hline Szinonima & 510 & $14 \%$ & $587^{*}$ & $17 \%$ \\
\hline Vesztés mint fejlődés, lehetőség & $356^{*}$ & $10 \%$ & 118 & $3 \%$ \\
\hline Attribúció & 178 & $5 \%$ & 138 & $4 \%$ \\
\hline Belső & 130 & $4 \%$ & 127 & $4 \%$ \\
\hline Külső & 48 & $1 \%$ & 11 & $0 \%$ \\
\hline Terület & 170 & $5 \%$ & $213^{*}$ & $6 \%$ \\
\hline Verseny & 105 & $3 \%$ & 122 & $4 \%$ \\
\hline Agresszió, háború & 72 & $2 \%$ & 68 & $2 \%$ \\
\hline Győzelem & 81 & $2 \%$ & $139^{*}$ & $4 \%$ \\
\hline Negatív társas reakciók & 71 & $2 \%$ & 57 & $2 \%$ \\
\hline Társak, társas támogatás & $45^{*}$ & $1 \%$ & 13 & $0 \%$ \\
\hline Egyéb & 119 & $3 \%$ & 97 & $\mathbf{3 \%}$ \\
\hline Összesen & 3665 & $100 \%$ & 3397 & $100 \%$ \\
\hline
\end{tabular}

A táblázatban " jelöli azt a csoportot, amely szignifikánsan nagyobb súllyal említette az adott kategóriát.

Ezek alapján úgy tűnik, hogy az EV csoport vesztés reprezentációjának inkább részét képezi, hogy a vesztéssel meg lehet és meg is kell küzdeni. A válaszok száma és változatossága arra enged következtetni, hogy nem csupán komplexebb az általuk felvázolt reprezentáció, de ők inkább rendelkeznek változatos eszközökkel a vesztéssel való megküzdéshez. A vesztés mint lehetőség kategória a megküzdés- 
hez szorosan kapcsolódó jelentéscsoport, a vesztés átkeretezésével történő feldolgozást ragadja meg, és a fogalom alapjaiban eltérő értelmezését mutatja a két csoport között. A külső attribúciók és a társas támogatás esetén feltárt különbségek a kategóriába tartozó asszociációk igen alacsony száma miatt viszont inkább marginálisnak tekinthetők.

A NEV-k vesztéssel kapcsolatos asszociációiban nagyobb súlyt kaptak az alábbiak:

- Érzelmek $(1136<1474, p<0,0001)$ - ezek túlnyomó része negatív érzelem volt. A csoport nagyobb relatív súllyal asszociált mind az aktiváló (például csalódottság, elégedetlenség, $339<366, p=0,0352)$, mind a deaktiváló (például szomorúság, bánat, $648<936, p<0,0001$ ), mind pedig a differenciálatlan érzelmekre (például rossz érzés, baj, $100<133, p=0,0062$ ). A legritkábban említett pozitív érzelmekben (például bátorság, öröm) nem volt szignifikáns különbség (49, illetve 39$)$;

- Szinonima $(510<587, p<0,0001)$ - például kudarc, vereség, bukás;

- Területek $(170<213, p=0,0027)$ - például sport, játék, pénz;

- Győzelem $(81<139, p<0,0001)$ - például győzelem, győztes, nyerés.

A NEV-k asszociációiról ezek alapján elmondható, hogy túlsúlyban inkább a kevésbé elaborált elemek (például érzelmek, szinonimák) szerepelnek benne.

A legnagyobb súllyal szereplő asszociációkat illetően szembeötlő a különbség. Míg a NEV csoport esetén a negatív érzelmi állapotok, illetve a vesztés szinonimái uralják a képet, addig az EV-knél a negatív érzelmek mellett megjelennek a vesztés átkeretezéséhez (például vesztés tapasztalat; tanulság), illetve az aktív megküzdéshez (újrapróbálkozás) kapcsolódó elemek. Úgy tűnik, hogy bár a vesztés az EV csoport számára is megterhelő érzelmi élmény, ők mégis inkább képesek konstruktívan értelmezni és kezelni azt.

7. táblázat. A legnagyobb súllyal szereplő asszociációk (Vesztés)

\begin{tabular}{|c|c|c|c|c|}
\hline & \multicolumn{2}{|l|}{ Eredményes versenyzők } & \multicolumn{2}{|c|}{ Nem eredményes versenyzők } \\
\hline 1 & Kudarc & 303 & Szomorú, szomorúság & 265 \\
\hline 2 & Csalódás, csalódottság & 198 & Kudarc & 224 \\
\hline 3 & Szomorú, szomorúság, szomorkodás & 193 & Bánat, bántódottság & 122 \\
\hline 4 & Tapasztalat, tapasztalatok & 101 & Verseny, versenyek & 85 \\
\hline 5 & Tanul, tanulás, tanulság, tanulságos & 99 & Vereség & 75 \\
\hline 6 & Verseny & 96 & Vesztes, veszteség & 72 \\
\hline 7 & Bánat, bánatosság & 62 & Siker, sikertelen, sikertelenség & 70 \\
\hline 8 & Vereség & 54 & Bukás & 68 \\
\hline 9 & $\begin{array}{l}\text { Újrapróbál, újrapróbálkozás, újra- } \\
\text { próbálkozik, újrapróbálás }\end{array}$ & 53 & Fájdalom & 61 \\
\hline 10 & Siker, sikertelen, sikertelenség & 51 & Győzelem, győztes & 48 \\
\hline
\end{tabular}




\section{ÖSSZEGZÉS}

Eredményeink tehát azt mutatják, hogy az EV-knek a versengéssel, a győzelemmel és a vesztéssel kapcsolatos asszociációi, ha nem is drámai, de statisztikailag kimutatható mértékben pozitívabbak és konstruktívabbak. Az ő versengésreprezentációjukban a NEV csoporthoz viszonyítva nagyobb súllyal jelenik meg a versengés motivációs aspektusa, a kapcsolódó pozitív érzelmek és állapotok, valamint az a gondolat, hogy a versengés az élet része. Emellett bár náluk is jelentős tényező, de alapvetően kevésbé hangsúlyos a verseny kimenetele, közvetlen eredménye. Mindezek miatt azt feltételezzük, hogy rájuk inkább egyfajta kevert orientáció jellemző, melyben az eredmény és a folyamat is jelentős. Az általuk alkalmazott koncepciót mindezek FÜLÖP (2013), illetve SEBESTYÉN és FÜLÖP (2015) kínai mintán nyert eredményeihez teszik hasonlatossá.

A győzelemről az EV-k nagyobb súllyal asszociálnak belső attribúciókra, ők feltehetőleg inkább gondolják, hogy kontrolljuk van az események felett (vö. FüLÖP, 1992). A győzelemmel járó eredmények közül számukra fontosabb a győzelemig megtett fejlődés, ami szintén a kevert eredmény- és folyamatorientáció meglétére utal. A vesztéssel kapcsolatban nagyobb súllyal asszociálnak az akár aktív, akár passzív megküzdésre, illetve hajlamosabbak a vesztésre mint lehetőségre tekinteni. Ez szintén összhangban van mind Fülöp (1992) tehetséges gyerekekkel, mind PINCZÉS-PRESSING és FÜLÖP (2013) tehetséges fiatal felnőttekkel végzett vizsgálataival.

A NEV csoport esetén az egyik legfeltűnőbb különbség eredményes társaikhoz képest, hogy asszociációik kidolgozatlanabbak és intellektuálisan szegényesebbek. Mindhárom fogalomra kevesebb asszociációt adnak, az asszociációik között pedig nagyobb súlyt kapnak a viszonylag egyszerüek és elaborálatlanok: például a hívószavak egyszerủ szinonimái, pozitív érzelmek (a győzelemnél), valamint a versengés területei és a hívószó antonímája (a vesztésnél). A versengés számukra negatívabb jelentésű fogalom és inkább a külsődleges eredményekről, mint a belső folyamatokról szól. A versengés hívószóról nagyobb súllyal asszociálnak negatív érzelmekre és állapotokra, valamint a lehetséges eredményekre (a győzelemre és a vesztésre), a győzelem hívószóból pedig a külső eredményekre (nyereményekre, díjakra) és a harcra. Mindezek mellett fontos azonban megemlítenünk, hogy FüLÖP (2013) eredményeihez viszonyítva még ők is némiképp pozitívabban viszonyulnak a versengéshez, mint az átlagos magyar fiatal felnőttek.

Mindezen különbségek alapvető szerepet játszhatnak a két csoport aktuális eredményeit, illetve leendő beválását illetően, és mint ilyenek, igen fontos gyakorlati következményekkel járhatnak és jelentős prevenciós lehetőségeket rejthetnek magukban. A fenti eredmények megmutatják, hogy a versenyeken elért eredmények valóban összefüggést mutatnak a versengéshez kapcsolt szubjektív jelentésekkel, és úgy véljük, hogy jól „diagnosztizálnak” olyan problémapontokat, melyeknél lehetőség lenne a hatékony pedagógiai beavatkozásra, hozzásegítve a tehetséges fiatalok szélesebb rétegeit a bennük rejlő potenciálok teljesebb kibontakoztatásához. 


\section{Korlátok és kitekintés}

A vizsgálat fontos korlátja, hogy a mintavételhez használt csatornákon és a tanári ajánláson kívül más tényező nem biztosította a két csoport intellektuális egyenrangúságát. Mégis úgy gondoljuk, hogy a tanárok számára biztosított útmutatás, a kifejezetten tehetséggondozással foglalkozó intézmények és szervezetek megcélzásával történő mintavétel, valamint a két alminta gondos illesztése elfogadható mértékben biztosította, hogy a vizsgált csoportok csupán a versenyeken felmutatott eredményesség szempontjából különbözzenek lényegesen. A vizsgálat másik fontos korlátja, hogy az alkalmazott módszer sajnos nem alkalmas ok-okozati öszszefüggések feltárására, így nem tudhatjuk, hogy a feltárt konceptuális különbségeknek valóban van-e közvetlen hatása az eredményességre. Ezen hipotézis bizonyításához további vizsgálatokra van szükség. Természetesen az sem vitatható, hogy a versenyeken való eredményességet és a kapcsolódó reprezentációkat feltételezhetően számos egyéb tényező is befolyásolhatja, többek között a válaszadók személyiségjellemzői (lásd például SHEARD, 2012), a versenykontextus szituatív tényezői és azok interakciói (FÜLÖP és TAKÁCS, 2013), illetve akár olyan környezeti tényezők is, mint a versenyzéssel kapcsolatos családi értékek és támogatás, a szocioökonómiai státusz vagy akár a versenyzéshez kapcsolódó iskolai gyakorlatok, hogy csak néhányat említsünk azok közül a faktorok közül, melyek nem képezték a jelen vizsgálat tárgyát. Úgy véljük, hogy a fentiek a versengés- és tehetségkutatás új, izgalmas nézőpontjait kínálják.

A felsoroltakon túl a jövőben mindenképpen gyümölcsöző lenne más korosztályok és kultúrák bevonásával, illetve longitudinális kutatási design alkalmazásával is megismételni a vizsgálatot. Fontos hozzáadott értéket jelentene az intellektuális képességek vizsgálatára alkalmas eszköz beépítése a vizsgálatba, ahogy jól meghatározott „beválási mutatók” beemelése is. Az ilyen eredmények további biztosítékául szolgálhatnának a jelen eredmények validitásának.

\section{IRODALOM}

Bicknell, B., \& Riley, T. (2012). The role of competitions in a mathematics programme. New Zealand Journal of Gifted Education, 17(1). Letöltve: www.giftedchildren.org.nz/apex

Bloom, D. B. (1985). Developing Talent in Young People. New York: Ballantine Books.

CAmpbell, J. R., \& WAlberg, H. J. (2011). Olympiad studies: Competitions provide alternatives to developing talents that serve national interests. Roeper Review, 33(1), 8-17.

Chen-YAO, K. (2011). The dilemma of competition encountered by musically gifted Asian male students: an exploration from the perspective of gifted education. High Ability Studies, 22(1), 19-42.

Connelly Stockton, J. C. (2012). Mathematical competitions in Hungary: Promoting a tradition of excellence \& creativity. Montana Mathematics Enthusiast, 9(1/2), 37-58.

DÁvid I., FÜlÖP M., PATAKY N. és RudAS J. (2014). Stressz, megküzdés, versengés, konfliktusok. Budapest: MATEHETSZ. 
FülÖP M. (1992). A tehetséges gyerekek versengő magatartásáról. Új Pedagógiai Szemle, 5, $3-13$.

FÜlÖP, M. (2001). Teachers' perception of the role of competition in their respective countries: Hungary, Japan and USA. Children's Social and Economic Understanding, 4(3), 142159.

FÜlÖP, M. (2002). Competition in Hungary and Britain perceived by adolescents. Alkalmazott Pszichológia, 3-4, 33-55.

FÜLÖP M. (2008). Verseny a társadalomban - verseny az iskolában. In BENEDEK A. és Hungler D. (szerk.), VII. Nevelésügyi Kongresszus. Az oktatás közügy (51-74). Budapest: Budapesti Műszaki és Gazdaságtudományi Egyetem.

FÜLÖP, M. (2009). Happy and unhappy competitors: what makes the difference. Psychological Topics, 18(2), 345-367.

FÜlÖP M. (2013). A versengés, a győzelem és a vesztés pszichológiája és kulturális különbségei. Értekezés. Budapest: MTA Doktori Tanács.

FÜLÖP M. és BERKICS M. (2003). Az iskolai versengés percepciója amerikai, japán és magyar középiskolások között. In III. Országos Neveléstudományi Konferencia - kivonatkötet (181). Budapest.

FÜLÖP M. és PRESSING Zs. (2012). Pedagógusok nézetei az iskola szerepéről a versengésre és a vállalkozásra való felkészítésben. Iskolakultúra, 2, 44-63.

FülÖP, M., Roland-Levy, C., \& Berkics, M. (2004). Economic competition perceived by French and Hungarian adolescents. In A. Ross (Ed.), The Experience of Citizenship (325331). London: London Metropolitan University.

Karnes, F. A., \& Riley, T. L. (1996). Competitions: Developing and nurturing talents. Gifted Child Today Magazine, 19(2), 14-15, 49.

Karnes, F. A., \& Riley, T. (2005). Competitions for Talented Kids: Win Scholarships, Big Prize Money, and Recognition. Waco: Prufrock Press.

OKTV 2013/2014 - Összesített adatok (2014). Letöltve: http://www.oktatas.hu/kozneveles/ tanulmanyi_versenyek/oktv_kereteben/dijazottak_eredmenyek/2013_2014_osszesitett_ adatok, 2014.06.11.

Orosz, G. (2010). Social representation of competition, fraud and academic cheating of French and Hungarian citizens. PhD thesis. University of Rheims.

PincZÉs-Pressing, Z., \& FülÖP, M. (2013). Competition as a field of competence for talented youth: Strategies of coping with winning and losing. In ISSBD Regional Workshop (57-58). Budapest: MTA KPI.

RILEY, T. L. (2011). Competitions for showcasing innovative and creative talents. Gifted and Talented International, 26(1-2), 63-70.

Riley, T. L., \& KARnes, F. A. (2009). Competitions. In B. Kerr (Ed.), Encyclopedia of Giftedness, Creativity, and Talent (165-168). Thousands Oaks, CA: Sage.

Rimm, S. B. (1986). Underachievement Syndrome: Causes and Cures. Watertown: Apple Publishing Company.

Roland-Levy, C., \& FÜlÖP, M. (2004). Perception of economic competition by French and Hungarian teenagers. In B. YANG LESTER (Ed.), Proceedings of the International Association for Research in Economic Psychology (1-26). Philadelphia: Drexel University.

Ross, A., Fülöp, M., \& Pergar Kuscer, M. (Eds.) (2006). Teachers' and Pupils' Constructions of Competition and Cooperation. A three-country study of Slovenia, Hungary and England. Ljubljana: Faculty of Education. 
SÁNDOR M., Orosz G. és FüLÖP M. (2010). A versengés, a győzelem és a vesztés szociális reprezentációja 8-9 éves kisiskolások körében. Pszichológia, 30(3), 175-205.

SEBESTYÉN N. és FÜlÖP M. (2015). A versengés, győzelem és vesztés szubjektív jelentése magyar, kínai és Magyarországon tanuló kínai diákok körében. Magyar Pszichológiai Szemle, 70(1), 143-158.

Sheard, M. (2012). Mental Toughness: The Mindset Behind Sporting Achievement. Second Edition. New York: Routledge.

SzALAY, L. B., \& BRENT, J. E. (1967). The analysis of cultural meanings through free verbal associations. Journal of Social Psychology, 72, 161-187.

SzAlay, L. B., \& DeESE, J. (1978). Subjective Meaning and Culture: An Assessment through World Associations. Hillsdale: Lawrence Erlbaum Associations.

Szalay, L. B., Strohl, J., Fu, L., \& LaO, P. F. (1994). American and Chinese Perceptions and Belief Systems: A People's Republic of China-Taiwanese Comparison. New York: Plenum Press.

UdVARI, S. J. (2000). Competition and the adjustment of gifted children: A matter of motivation. Roeper Review, 22(4), 212-216.

White, B. L., Kaban, B. T., \& Attanucci, J. S. (1979). The Origins of Human Competence: Final Report of the Harvard Preschool Project. Lexington: D. C. Heath.

\title{
EXAMINATION OF YOUNG COMPETITORS' CONCEPTIONS ABOUT COMPETITION, WINNING AND LOSING USING THE ASSOCIATIVE GROUP ANALYSIS METHOD
}

\author{
PINCZÉS-PRESSING, ZSUZSANNA - SEBESTYÉN, NÓRA - BERKICS, MIHÁLY - \\ FÜLÖP, MÁRTA
}

Based on previous studies we can assume that gifted individuals have a more positive and constructive view of competition than their average peers (FÜLÖP, 1992; PINCZÉS-PRESSING \& FÜLÖP, 2013). However, to our knowledge there is no scientific evidence, which would examine the possible difference between equally highly able, but unequally successful individuals' concepts about competition, winning and losing. Because of this, as a part of a bigger research project, we conducted an online study using Associative Group Analysis methodology (SZALAY \& BRENT, 1967) with the stimulus words competition, winning and losing. Our sample matched both by age and gender included 400 young individuals (average age was 17.96 years): 200 successful competitors and 200 unsuccessful competitors. According to our results, the successful competitors had a more complex and positive view about the investigated concepts. In their associations regarding competitions there was a greater emphasis on motivational aspects and positive emotions. Their associations reflected result-and process-orientation at the same time. Moreover, the successful competitors were more likely to see losing as an opportunity and they associated a number of coping strategies to it compared to the less elaborated concept of the unsuccessful group.

Key words: Associative Group Analysis, competition, winning, losing, giftedness 